\title{
EMPIRICAL INVESTIGATION OF THE EFFECTS OF INDUSTRY TYPE AND FIRM SIZE ON EXPORT BARRIERS
}

\author{
Joaquim Ramos SILVA ${ }^{1}$, Mário FRANCO², André MAGRINHO ${ }^{3}$ \\ ${ }^{1}$ SOCIUS/CSG, Department of Economics, ISEG, University of Lisbon, \\ Rua Miguel Lúpi, 20 - 1249-078 Lisboa, Portugal \\ ${ }^{2}$ CEFAGE - UBI Research Center, Department of Management and Economics, \\ University of Beira Interior, Estrada do Sineiro - 6200-209 Covilhã, Portugal \\ ${ }^{3}$ Portuguese Industrial Association - Employers' Confederation, \\ Praça das Indústrias - 1300-307 Lisboa, Portugal \\ E-mails: 1jrsilva@iseg.ulisboa.pt (corresponding author); \\ 2mfranco@ubi.pt; ${ }^{3}$ andre.magrinho@aip.pt
}

Received 07 April 2015; accepted 15 January 2016

\begin{abstract}
This study aims to explore the importance of export barriers and to achieve this by comparing different industry types and firm sizes. We performed a cross-sectional study of 529 Portuguese export firms drawn from the database held by a Portuguese Industrial Association - Business Confederation. From multivariate analysis of variance and the Tukey's HSD (Honestly Significant Difference) test, we conclude that the more important export barriers mentioned by the firms proved more external than internal. Our results also show that the service and retail trade sectors were the sectors reporting the greatest peculiarities regarding export barriers. Thus, we identify an "industry effect" as regards export barriers even while our findings do not indicate any "size effect". Knowing the industry-specific export barriers enables companies not only to better coordinate and perform export processes but also to better anticipate the behaviour of their competitors. Other practical and theoretical implications will also be presented.
\end{abstract}

Keywords: export barriers, internationalization, globalization, industry, firm size, Portugal.

JEL Classification: M10, M16, M21.

\section{Introduction}

Export barriers in a firm's environment may display many facets and across two different levels: internal and external to the firm (Suarez-Ortega 2003; Uner et al. 2013). In the era of globalization, identifying export barriers appears a fairly useful means of working the chain of perceptions, interpretations and actions that enable firms to adapt to their surroundings and aim for successful internationalization processes.

Some studies have contributed to the elimination or reduction of these barriers (see Richardson 1993, for the case of the United States). Indeed, export barriers emerge as major limitations to the internationalization process but, whenever correctly identi- 
fied, susceptible to overcoming through the good preparation that leads firms to take the appropriate steps (see Dent 2002, for the case of East Asian countries). However, not all firms have the same capacities in this endeavour and the final result depends considerably on their respective industry and size. These dimensions have been relatively overlooked in the literature on export barriers. In the present paper, we analyse these differences among firms and their effects when dealing with export barriers in the Portuguese case. This is of interest not only due to the subject itself but also because the country has displayed major shortcomings at this level with exports structurally and consistently lagging behind imports (Silva 2008; Silva, Simões 2012).

Thus, in order to obtain greater levels of the beneficial effects generated by export activities, there is an increased need to study export barriers. Several published studies have focused on particular industries but the overall discussion of export barriers from this perspective remains somewhat scanty. Empirical evidence points toward the existence of certain variances between industries, for example, export barriers are generally higher in the service sector than in the manufacturing sector (e.g., Kedia, Chhokar 1986; Da Silva, Da Rocha 2001). To our knowledge, there are as yet no consensual studies about export barriers across various industries within the Portuguese context.

In spite of the potential benefits, starting up exportation processes constitutes a difficult decision because this inevitably implies risks and especially for small and medium-sized enterprises (SMEs). For this reason, the literature on export barriers has centred on SMEs in recent decades (e.g., Andersson et al. 2004; Narayanan 2015). Export barriers have also caused a change in how SMEs operate in terms of engaging with export markets. Moreover, the current competitive and global environments, as well the relative absence of slack resources, force SMEs to cope with greater complexity (Strandholm, Kumar 2003). As noted by Calof (1994), small firms differ from large firms in several important respects that may affect their response to export barriers. Despite some studies approaching the differences in export barriers between large companies and SMEs (e.g., Andersson et al. 2004; Nadkarni, Perez 2007; Rundh 2007; Katsikeas, Morgan 1994; Suarez-Ortega 2003), this does not particularly hold for the Portuguese case.

To overcome this research gap, the main objective of this paper involves exploring the importance of export barriers and achieves this by comparing different industry types and firm sizes. Hence, this study focuses on answering the following research question: are export barriers influenced by industry type and firm size? In fact, there has been little research analysing the joint effect of both industry type and firm size and, in particular, our research represents one of the very first attempts to study these joint barrier effects on Portuguese exporting firms.

\section{Literature review and hypotheses development}

\subsection{Export barriers}

An important model in the area of exports points to four categories of barriers (Ramaswami, Yang 1990): (1) export knowledge, (2) limited internal resources, (3) procedural barriers and (4) external variables. Okpara and Koumbiadis (2009) and Rajendran 
(2015) also studied the conceptual structure of export barriers and identify the following key export barriers: resource constraints, knowledge barriers, corruption, lack of export assistance and poor infrastructures.

Al-Hyari et al. (2012) and Rajendran (2015) classified export barriers broadly either as internal or external. Internal barriers are associated with organizational resource capacities and a company's approach to the export business. More precisely, these internal barriers break down into factors relating to information (difficulty in accessing information), functional (lack of new technology or capabilities) financial (lack of financial resources), product marketing (quality, new products, export, technical), price (uncompetitive pricing), distribution (complexity access), and logistics (transportation costs, facilities). External barriers stem from the home and host environment within which the firm operates. These external factors may be procedural (documentation, communication), governmental (lack of incentives, inadequate regulations), task (competition in export markets), environmental - economic (currencies, economic situation), political legal (instability, changes in regulations) and socio-cultural (language, cultural differences).

In a domestic setting, important difficulties interrelate with the institutions and the national business environment surrounding firms in each country. For example, companies may not encounter the incentives appropriate to exporting (this often proves the case either in countries where public policies, whatever gets officially proclaimed, tend to favour the non-traded goods and service sectors or in countries with large scale domestic markets). Access to insurance and financing for international operations and activities is relatively more intricate and onerous, as we return to below, and particularly whenever infrastructure, logistical and institutional support, etcetera is lacking. From the perspective of trade policy, imperfections in capital markets, for example high interest rates and costly credit, especially in the initial stages of internationalisation processes, were long ago identified as among the major hurdles for exporting firms (Corden 1998).

Insofar as they inherently imply rivalry (Gomory, Baumol 2000), exports also find barriers in the destination countries. Indeed, various forms of impediments still persist in many importing countries, for example due to the power of rivals in imperfect markets and bureaucratic and technical procedures (Kerr 2007; Hobbs 2007) despite all the "trade facilitation" measures implemented in the meanwhile (Hoekman, Kostecki 2001), including recent multilateral efforts (Sourdin, Pomfret 2012). Additionally, destination countries increasingly deploy less visible forms of restrictions as well as barriers of cultural origin appearing (Rauch 2001). Furthermore, even international trade regulations may often serve to protect national firms from foreign competition and thereby raising barriers to exports, as is the case with anti-dumping and anti-cartel actions (Alexander, Warwick 2007).

Among the various barriers associated with exportation processes, the financial factor proves of particular importance. As regards this, some researchers have pointed out a shortage of financial resources for establishing exports and their related financial operations (Ortega 2003; Wheeler et al. 2008; Katsikeas et al. 2009), the need to use letters 
of credit, the lack of personnel able to devote their working time to export activities (Ortega 2003) and the lack of the necessary capacity for mass production as representing the most important factors (Abassi et al. 2012). Furthermore, various studies have approached the competitive intensity of markets and identifying this factor as one of the leading barriers to exports subject to research. This barrier results from international market instability and mainly derives from the effects of other variables in terms of market competitors (Rundh 2007), foreign governments and the supply and demand conditions in effect. Such variables prove particularly powerful and impact on the exports of any company.

Research has also focused on export credits, covering the multiple aspects of this activity, particularly insurance (Zammit et al. 2009). One of the problems stems from to a greater or lesser extent generalized handicap for firms at this level, and as stressed above particularly when starting out on their activities outside the home market, there is a tendency for some degree of public intervention justified as being for the "public good" with regard to "market failures" and providing an effective subsidy for exports with such policies discussed in Easterly et al. (2009). Another outcome of this interventionist trend involved the creation of export-import banks or agencies, with many awarded at least partial public guarantees. This became a highly sensitive issue in international economic policy, within the World Trade Organization (WTO) context for instance. A study of five cases by Raynauld (1992) showed how financing exports to developing countries, largely guaranteed by public entities, introduced distortions between trade partners harming economic development and competition. As a result, such insurance schemes became almost impossible to operate, at least directly, due to WTO regulations (Dewit 2001) following recognition of the risks of their capture "by rent seekers" (Hoekman, Smarzynska-Javoricik 2004). Furthermore, the increase in export-oriented policies as promoters of growth and development (Dent 2002) emphasised how the solution to such problems reside in the better and more appropriate functioning of capital markets rather than subsidies.

To sum up, due to the great diversity of export barriers and the fact that empirical studies have proved their effectiveness in many cases, our study concentrates on four types: external demand, external competition, financing and export credit insurance, which, in our view, form the most significant barriers for exporting firms. Table 1 summarises these four export barriers and the previous studies investigating them.

\subsection{Research hypotheses}

Studies on the barriers to exports have taken both different perspectives and different industries (Abassi et al. 2012), and a number of case studies targeted one specific industry (Sullivan, Bauerschmidt 1988). In the last case, for example, manufacturing (Abdul-Talib et al. 2011; Karelakis et al. 2008; Kahiya et al. 2014), the high-tech sector (Richardson 2011), services (Beaulieu 2007) and the car industry (Abassi et al. 2012), among others. However, such a research design does not return any comparison of perceptions among firms in different industries. 
Table 1. Export barriers and related authors

\begin{tabular}{ll}
\hline \multicolumn{1}{c}{ Export Barriers } & \multicolumn{1}{c}{ Author(s) } \\
\hline External demand & $\begin{array}{l}\text { Alexander and Warwick (2007); Thomas and Araujo (1985); } \\
\text { Vivekanandan and Rajendran (2006) }\end{array}$ \\
\hline $\begin{array}{l}\text { External } \\
\text { competition }\end{array}$ & $\begin{array}{l}\text { Leonidou (1995); Katsikeas and Morgan (1994); Lloyd and Morrissey (2001); } \\
\text { Cheong and Chong (1988); Crick and Chaudhry (2000); } \\
\\
\text { Tesfom and Lutz (2006) }\end{array}$ \\
\hline Financing & $\begin{array}{l}\text { Leonidou (1995); Leonidou (2000); Kaleka and Katsikeas (1995); Hoekman } \\
\text { and Smarzynska-Javoricik (2004); Shaw and Darroch (2004); Ortega (2003); }\end{array}$ \\
& Katsikeas et al. (2009) \\
\hline $\begin{array}{l}\text { Export credit } \\
\text { insurance }\end{array}$ & $\begin{array}{l}\text { Raynauld (1992); Hoekman and Smarzynska-Javoricik (2004); } \\
\text { Zammit } \text { et al. (2009). }\end{array}$ \\
\hline
\end{tabular}

The perception of export barriers seems to vary according to industry type (Da Silva, Da Rocha 2001). In his early literature review of export studies, Bilkey (1978) also reports that obstacles perceived by management tend to vary by industry. This finding also appears in subsequent studies (e.g., Da Silva, Da Rocha 2001), which find significant differences in the perception of obstacles to exporting across different industries.

The perception of export barriers also seems to vary according to firm size (e.g., Da Silva, Da Rocha 2001; Mittelstaedt et al. 2003; Andersson et al. 2004; Nadkarni, Perez 2007). Firms with greater resources tend to have greater international commitments. Rundh (2007) also notes that the lack of resources and knowledge prove to be important barriers to internationalisation. In fact, the negative role export barrier perceptions play in the internationalisation behaviours of medium and small enterprises has attracted the attention of many researchers in the international business field (Katsikeas, Morgan 1994; Suarez-Ortega 2003).

The relationship between firm size and management perceptions of barriers to exporting in most cases return significant results with larger and smaller firms perceiving those obstacles differently (e.g., Leonidou 1995). Katsikeas and Morgan (1994) suggest that while firm size interrelates with some of the export barriers perceived by managers this does not hold for all of them. The study by Calof (1994) come up with a positive relationship between firm size and exporting activities while Burton and Schlegelmilch (1987) conclude in favour of a negative relationship.

Finally, taking into account the earlier literature, we also believe there is a particular relationship between export barriers and both industry sector and firm size. We thus propose the following hypotheses.

H1: Industry type exerts an influence on export barriers.

H2: Firm size exerts an influence on export barriers.

H3: The joint effect of industry type and firm size exerts an influence on export barriers. 


\section{Methods}

\subsection{Sample and data collection}

Within the context of our study, we sourced data from the Portuguese Industrial Association - Business Confederation (henceforth with the acronym AIP-CE), the main business association in Portugal, founded in 1837, and at the time of the inquiry with 4403 directly affiliated firms. In Portugal, the AIP-CE plays a leading role in nurturing technical and commercial expertise among Portuguese firms, particularly in the fields of training, quality, innovation, internationalisation and competitiveness. Thus, the Portuguese business environment represents an appropriate laboratory for testing the hypotheses of our research project.

Data collection took place in a database set up by AIP-CE from the 2012 Entrepreneurial Activity survey. From the total of 1045 firms participating in the survey, we selected 572 export firms for our study. However, of this total, we incorporated only 529 of these export firms in our analysis as some only partially filled in the questionnaire. Besides gathering general demographic information about the firms, our dataset contained some dimensions/variables concerning export barriers. We would note that, in this work, we consider as export firms those selling part of their production outside the home market, regardless of its value and relative weight in the respective firm's business turnover. This data set has never before been applied for similar purposes.

\subsection{Variables and measures}

Independent Variables. These variables were determined by asking respondents to indicate where in the Statistical Classification of Economic Activities in the European Community (NACE) their firm ranked. For our research purpose, on the one hand, industrial sectors were classified into five subgroups comprising manufacturing, construction, retail trade, services and others. On the other hand, in order to classify business units as SMEs, the number of employees served as the defining criterion, i.e., fewer than 250 employees (cf. European Commission Recommendation 2003/361/EC), i.e., our sample correspondingly divided up into micro, small, medium and large firms.

Dependent Variables. From the literature review, we apply four main dimensions/variables of great relevance to enabling firms to overcome export barriers: (1) External demand (2) External competition, (3) Financing and (4) Export credit insurance. These export barriers arise out of the prior research on internationalization and correspondingly systematised and deployed by several scholars (see Table 1). In particular, respondents evaluated these different export barriers on a five-point Likert scale from 1 "not important at all" to 5 "very important".

\subsection{Data analyses}

We applied several statistical analysis processes to the data obtained to fulfil the research objectives and to empirically validate the hypotheses. Firstly, this involved the descriptive analysis (mean and standard deviations) of the various export barriers identified by firms. Secondly, Cronbach's Alpha served to validate the internal variable consistency (Churchill 1979), as well as multivariate analysis of variance (MANOVA) and Tukey's HSD (Honestly Significant Difference) test. 


\section{Findings and discussion}

\subsection{Descriptive results}

The sample includes firms operating in several economic sectors and the firm size is predominantly. Exports represent less than $50 \%$ of sales in $67 \%$ of firms, a consequence of their focus on the domestic market (Table 2).

Table 2. Sample characterisation

\begin{tabular}{lcc}
\hline \multicolumn{1}{c}{ Subgroups } & Count & Percentage \\
\hline Industry & & \\
Manufacturing & 335 & 63.3 \\
Construction & 16 & 3.0 \\
Retail trade & 118 & 22.3 \\
Services & 53 & 10.0 \\
Others & 7 & 1.3 \\
\hline Size & & \\
Up to 10 employees & 87 & 16.4 \\
Between 11 and 50 & 202 & 38.2 \\
Between 51 and 250 & 169 & 31.9 \\
More than 250 & 71 & 13.4 \\
\hline Exports & & \\
Up to 10\% & 190 & 36.0 \\
11-50\% & 164 & 31.0 \\
50-75\% & 74 & 14.0 \\
76-100\% & 101 & 19.0 \\
\hline
\end{tabular}

The analysis of different export barriers is based on their mean frequency and standard deviations (SD), as shown in Table 3. The internal consistency of the four groups of export barriers indicates a Cronbach's alpha of 0.682 for the total scale, which indicates acceptable reliability of the instrument used in this study (Churchill 1979). However, in this research, we look for a broad representativeness of firms, even at the risk of some heterogeneity.

As shown in Table 3, the results obtained reveal that Portuguese firms face different export barriers in general. Correspondingly, the findings report that barriers such as "external demand" and "external competition" prove the most important for the firms in our study.

Table 3. Descriptive statistics

\begin{tabular}{lccccccc}
\hline \multicolumn{1}{c}{ Export barriers } & Mean & SD & 1 & 2 & 3 & 4 & 5 \\
\hline External demand & 4.09 & 1.094 & 3.8 & 5.9 & 15.5 & 27.6 & 47.3 \\
\hline External competition & 3.86 & 1.017 & 3.6 & 4.7 & 24.0 & 37.6 & 30.1 \\
\hline Financing & 3.13 & 1.354 & 17.4 & 14.2 & 25.3 & 23.8 & 19.3 \\
\hline Export credit insurance & 3.00 & 1.377 & 20.6 & 15.5 & 24.8 & 21.7 & 17.4 \\
\hline
\end{tabular}

Note: $\mathrm{N}=529$; The mean for each individual barrier is the average on a scale: 1 - Not important at all; 2 - Unimportant; 3 - Indifferent; 4 - Important; 5 - Very important. 


\subsection{Exploratory results}

As stated, to validate our research hypotheses, we applied MANOVA to examine the effect of the two independent variables (industry and firm size) on the four export barriers. Thus, to measure the influence of the independent variables on the totality of the dependent variables, we drew upon the various multivariate tests designed to calculate such hypotheses. In Table 4, we present the results of the four tests feasible and reporting an acceptable observed power, ranging from 0.529 to 0.999 . Therefore, the size influence on the sample is practically equal to the size influence on the population.

Table 4. Multivariate tests

\begin{tabular}{llcccc}
\hline \multicolumn{1}{c}{ Effect } & \multicolumn{1}{c}{ Test } & Value & F & Sig. & Observed power \\
\hline Industry & Pillai's Trace & 0.095 & 3.090 & 0.000 & 0.999 \\
& Wilks' Lambda & 0.908 & 3.099 & 0.000 & 0.990 \\
& Hotelling's Trace & 0.098 & 3.091 & 0.000 & 0.999 \\
& Roy's Largest Root & 0.044 & 5.590 & 0.000 & 0.978 \\
\hline Firm size & Pillai's Trace & 0.021 & 0.879 & 0.568 & 0.529 \\
& Wilks' Lambda & 0.979 & 0.880 & 0.567 & 0.530 \\
& Hotelling's Trace & 0.021 & 0.881 & 0.566 & 0.999 \\
& Roy's Largest Root & 0.018 & 2.298 & 0.058 & 0.669 \\
\hline Industry*Firm size & Pillai's Trace & 0.071 & 0.835 & 0.772 & 0.910 \\
& Wilks' Lambda & 0.931 & 0.835 & 0.771 & 0.892 \\
& Hotelling's Trace & 0.073 & 0.836 & 0.770 & 0.911 \\
& Roy's Largest Root & 0.037 & 1.723 & 0.065 & 0.847 \\
\hline
\end{tabular}

Having identified the significant effects of the factors on dependent variables subject to study, we proceed with the analysis of the reported variance. As regards the significant effect of the "industry" variable, the results show that this does impact on all export barriers: "External demand", "External competition", "Financing" and "Export credit insurance". In particular, the different multivariate tests indicate an overall effect of industry type on our set of dependent variables, considered as a group $(\mathrm{p}<0.001)$ - Table 5 .

As regards the significant effect of the "firm size" variable on export barriers, our results report no statistically significant influence. Katsikeas and Morgan (1994) also identified this empirical finding. In addition, our analytical results do not point towards any statistically joint effect of the two independent variables. Thus, as a preliminary outcome, only the industry sector seems to exert an influence on export barriers.

Table 5. Tests of between-subjects effects

\begin{tabular}{lcccccc}
\hline \multirow{2}{*}{ Export Barriers } & \multicolumn{2}{c}{ Industry } & \multicolumn{2}{c}{ Firm size } & \multicolumn{2}{c}{ Industry*Size } \\
\cline { 2 - 7 } & $F$ & $p$ & $F$ & $p$ & $F$ & $p$ \\
\hline External demand & 3.376 & $0.010^{* * *}$ & 1.193 & 0.312 & 0.927 & 0.514 \\
\hline External competition & 2.794 & $0.026^{* *}$ & 1.215 & 0.303 & 1.439 & 0.152 \\
\hline Financing & 2.844 & $0.024^{* *}$ & 0.297 & 0.827 & 0.633 & 0.801 \\
\hline Export credit insurance & 3.741 & $0.005^{* * *}$ & 0.881 & 0.451 & 0.707 & 0.732 \\
\hline
\end{tabular}

Note: $* * * \mathrm{p}<0.01 ; * * \mathrm{p}<0.05 ; * \mathrm{p}<0.1$. 
To examine the between-group differences among the four industry sectors, we applied Tukey's Post-hoc HSD test. The results display significant differences between the manufacturing and retail trade sectors and the service sector as regards "External demand" ( $p<0.01)$. Concerning "External competition", we found that the retail trade and construction sectors attribute relatively more weight to this export barrier than the manufacturing industry ( $\mathrm{p}<0.05$ and $\mathrm{p}<0.1$, respectively). However, in terms of "Export credit insurance" we report that the service sector awards relatively more weight to this barrier than the manufacturing industry $(p<0.05)$. In collective terms, there were some differences with respect to export barriers although mainly focused on the service and retail trade sectors. This is not surprising insofar as manufacturing is more export-oriented than services or retail trade. However, since a number of export barriers do report significant differences in their relevance to different industries, we correspondingly affirm Hypothesis 1 .

With regard to firm size, according to Tukey's HSD test, export barriers such as "External demand" and "Financing" display a clear trend: large firms attribute significantly less weight to this barrier than SMEs $(\mathrm{p}<0.05)$. Thus, firm size does not have an overall effect on export barriers. Therefore, we reject our Hypothesis 2. Our empirical evidence does not support the position of Calof (1994), whereby a greater variety of export barriers vary according to firm size. However, our results show there is a difference between large and small firms. So more accurately, we draw attention to the fact that the size effect in itself does not especially impact on the exporting processes. These trends suggest that comparative advantage (through the exports of some industries' products) is more relevant than the simple effect of firm size, as concluded for example by Easterly et al. (2009).

As regards the interactions between the two variables "Industry*Size", and analysing Table 5, we find that such interactions do not hold a significant influence over the export barriers. As already concluded from the multivariate tests, calculation of between-subjects effects confirms this prediction. The statistical analysis did not show any significant differences among the individual export barriers. In the light of these insights, we must also reject our Hypothesis 3, which is a consequence of the previous findings.

\section{Conclusions and implications}

This article's objective involves enhancing knowledge on export barriers across industry type and firm size. Taking into account the relevance of export barriers for firms confronting tough competition in global markets, our findings show that the industry type really does matter to these barriers, especially External demand, External competition, Financing and Export credit insurance. However, the results also indicate that firm size subgroups do not influence export barriers.

Firstly, analysing the industry effect, we may conclude that services and the retail trade face the most export barrier peculiarities as firms in these sectors rely less on exports for example, even though the service sector is far from homogeneous. While the service sector is widely market-oriented and the manufacturing sector is mostly export-oriented, 
at this stage of the research, we do not think there is a high risk of heterogeneity, and later, on the basis of these differences, other studies should advance to more precise results by sector or industry.

Secondly, the "size effect" does not contribute to the relative importance of the export barriers studied and contrary to what was expected. According to our results, it is clear that the industry effect is much more relevant than firm size. This has deep roots in economic theory insofar as the strength of the specialization effect is evident rather than that of firm size. In fact, "size effect in itself does not especially impact on the exporting processes", if the firm is in a competitive industry. This is particularly true if we compare with the "industry effect".

Our study presents theoretical and practical implications. It provides certain contributions to the theory in accordance with its analysis of the joint effects of industry type and firm size on export barriers. Regarding export barriers as a whole, in spite of the results obtained, we may conclude such obstacles are partly influenced by size and industry. Due to the small number of studies showing empirical evidence about their interface, this investigation offers a more integrative and holistic vision of the relative importance of firm size and industry domain for export processes.

A number of implications relevant to policy-makers and business executives (practical implications) also derive from the present study. Despite our study suggesting that a greater variety of export barriers do not significantly vary according to firm size, this does not mean that small firms should not pay attention to the competitiveness in external markets and seek out those areas willing to pay more for their products and services while simultaneously seeking to reduce internal costs. In fact, this company segment when compared with their larger counterparts is demonstrably more exposed to various types of barriers hindering their entrance into international markets.

Finally, in spite of the contributions deriving from the empirical evidence generated, the study carried out is subject to several drawbacks that require this investigation to be continued. As far as the sample is concerned, we may in the future deepen the study of the effects of the differences in industry sectors and firm size with regard to export barriers. However, our study was carried out solely on companies and firms operating in some Portuguese sectors, and our sample was restricted to Portuguese exporting firms and their environments. Thus, to overcome this limitation and to enable the generalisation and universal application of our conclusions and implications, further studies are necessary analysing other sectors, countries and cultures. Finally, although domestic firms largely prevail in the sample we used, specific issues related to foreign direct investment and the presence of multi-national firms were not scrutinised in our study. Therefore, we mention the need to approach such issues in future research.

\section{Acknowledgements}

The authors would like to thank the anonymous reviewers for their helpful comments which contributed to the development of this paper. We gratefully acknowledge financial support from FCT and FEDER/COMPETE through grant PEst-C/EGE/UI4007/2013. 


\section{References}

Abassi, M. R.; Shakhsian, F.; Fayyazi, M. J.; Rezaie, M. 2012. Identifying the most important export barriers in Iran case study: auto-part industry, International Journal of Academic Research in Economics and Management Sciences 1(1): 63-81.

Abdul-Talib, A.; Salleh, M. F.; Shamsuddin, F. M.; Ashari, H. 2011. The effects of firm size and international business experience on export attitudes, ACR 19(1-2): 4-14.

Al-Hyari, K.; Al-Weshah, G.; Alnsour, M. 2012. Barriers to internationalisation in SMEs: evidence from Jordan, Marketing Intelligence \& Planning 30(2): 188-211.

http://dx.doi.org/10.1108/02634501211211975

Alexander, C.; Warwick, K. 2007. Governments, exports and growth: responding to the challenges and opportunities of globalization, The World Economy 30(1): 177-194.

http://dx.doi.org/10.1111/j.1467-9701.2007.00877.x

Andersson, S.; Gabrielsson, J.; Wictor, I. 2004. International activities in small firms: examining factors influencing the internationalization and export growth of small firms, Canadian Journal of Administrative Sciences 21(1): 22-34. http://dx.doi.org/10.1111/j.1936-4490.2004.tb00320.x

Beaulieu, E. 2007. Trade in services, in W. A. Kerr, J. D. Gaisford (Eds.). Handbook of international trade policy. Cheltenham/UK: Edward Elgar, 150-162.

http://dx.doi.org/10.4337/9781847205469.00022

Bilkey, W. J. 1978. An attempted integration of the literature on the export behavior of firms, Journal of International Business Studies Spring/Summer: 33-46.

http://dx.doi.org/10.1057/palgrave.jibs.8490649

Burton, F. N.; Schlegelmilch, B. B. 1987. Profile analysis of non-exporters versus exporters grouped by export involvement, Management International Review 27(1): 38-49.

Calof, J. L. 1994. The relationship between firm size and export behaviour revisited, Journal of International Business Studies 25(2): 367-387. http://dx.doi.org/10.1057/palgrave.jibs.8490205

Cheong, W. K.; Chong, K. W. 1988. Export behavior of small firms in Singapore, International Small Business Journal 6(2): 34-41. http://dx.doi.org/10.1177/026624268800600203

Churchill, Jr., G. A. 1979. A paradigm for developing better measures of marketing constructs, Journal of Marketing Research 16(1): 64-73. http://dx.doi.org/10.2307/3150876

Corden, W. M. 1998. Trade policy and economic welfare. 2nd ed. Oxford: Oxford University Press.

Crick, D.; Chaudhry, S. 2000. Small businesses' motives for exporting the effect of internationalization, Journal of Marketing Practice: Applied Marketing Science 3(3): 156-170.

http://dx.doi.org/10.1108/EUM0000000004340

Da Silva, P. A.; Da Rocha, A. 2001. Perception of export barriers to Mercosur by Brazilian firms, International Marketing Review 18(6): 589-611. http://dx.doi.org/10.1108/EUM0000000006296

Dent, C. M. 2002. The foreign economic policies of Singapore, South Korea and Taiwan, Cheltenham, UK: Edward Elgar.

Dewit, G. 2001. Intervention on risky export markets: insurance, strategic action or aid?, European Journal of Political Economy 17(3): 579-592. http://dx.doi.org/10.1016/S0176-2680(01)00046-5

Easterly, W.; Reshef, A.; Schwenkenberg, J. 2009. The power of exports. Policy Research Working Paper 5081. World Bank.

Gomory, R. E.; Baumol, W. J. 2000. Global trade and conflicting national interests. Cambridge, Massachusetts: The MIT Press.

Hobbs, J. H. 2007. Technical barriers to trade, in W. A. Kerr, J. D. Gaisford (Eds.). Handbook of international trade policy. Cheltenham, UK: Edward Elgar, 394-403.

http://dx.doi.org/10.4337/9781847205469.00048 
Hoekman, B. M.; Kostecki, M. M. 2001. The political economy of the world trading system: the WTO and beyond. 2nd ed. Oxford: Oxford University Press.

http://dx.doi.org/10.1093/019829431X.001.0001

Hoekman, B.; Smarzynska-Javoricik, B. 2004. Policies facilitating firm adjustment to globalization. Policy Research Working Paper 3441. Washington, DC: World Bank.

Kahiya, E. T.; Dean, D. L.; Heyl, J. 2014. Export barriers in a changing institutional environment: a quasi-longitudinal study of New Zealand's manufacturing exporters, Journal International Entrepreneurship 12(4): 331-364. http://dx.doi.org/10.1007/s10843-014-0131-7

Karelakis, C.; Mattas, K.; Chryssochoidis, G. 2008. Export problems perceptions and clustering of Greek wine firms, EuroMed Journal of Business 3(1): 6-22.

http://dx.doi.org/10.1108/14502190810873795

Katsikeas, C. S.; Leonidou, L. C.; Samiee, S. 2009. Research into exporting: theoretical, methodological and empirical insights. The SAGE Handbook of International Marketing.

Katsikeas, C.; Morgan, R. 1994. Differences in perceptions of exporting problems based on firm size and export market experience, European Journal of Marketing 28(5): 79-85.

http://dx.doi.org/10.1108/03090569410062014

Kedia, B. L.; Chhokar, J. 1986. Factors inhibiting export performance of firms: an empirical investigation, Management International Review 26(4): 33-43.

Kerr, W. A. 2007. Administrative measures: restraining bureaucracy from inhibiting trade, in W. A. Kerr, J. D. Gaisford (Eds.). Handbook of international trade policy. Cheltenham, UK: Edward Elgar, 330-336. http://dx.doi.org/10.4337/9781847205469.00040

Leonidou, L. C. 1995. Empirical research on export barriers: review, assessment and synthesis, Journal of International Marketing 3(1): 29-43.

Leonidou, L. C. 2000. Barriers to export management: an organizational and internationalization analysis, Journal of International Management 6(2): 121-148.

http://dx.doi.org/10.1016/S1075-4253(00)00022-3

Lloyd, T. O.; Morrissey, G. R. 2001. Estimating the impact of anti-dumping and anti-cartel actions using intervention analysis, Economic Journal 108(447): 458-476.

http://dx.doi.org/10.1111/1468-0297.00298

Mittelstaedt, J. D.; Harben, G. N.; Ward, W. A. 2003. How small is too small? Firms' size as a barrier to exporting from the United States, Journal of Small Business Management 41(1): 68-84. http://dx.doi.org/10.1111/1540-627X.00067

Nadkarni, S.; Perez, P.D. 2007. Prior condition and early international commitment: the mediating role of domestic mindset, Journal of Business Studies 38(1): 160-176.

http://dx.doi.org/10.1057/palgrave.jibs. 8400248

Narayanan, V. 2015. Export barriers for small and medium-sized enterprises: a literature review based on Leonidou's model, Entrepreneurial Business and Economics Review 3(2): 105-123. http://dx.doi.org/10.15678/EBER.2015.030208

Okpara, J. O.; Koumbiadis, N. J. 2009. Strategic export orientation and internationalization barriers: evidence from SMEs in a developing economy, Journal of International Business and Cultural Studies 1(1): 1-10.

Ortega, S. S. 2003. Export barriers, insights from small and medium-sized firms, International Small Business Journal 21(4): 403-419. http://dx.doi.org/10.1177/02662426030214002

Rajendran, R. 2015. Influence of information systems strategic orientation on SMEs' perception of export barriers, South Asian Journal of Management 22(2): 119-143. 
Ramaswami, S. N.; Yang, Y. 1990. Perceived barriers to exporting and export assistance requirements, in S. T. Cavusgil, M. R. Czinkota (Eds.). International perspectives on trade promotion and assistance. CT: Quorum Books, Wetport, 187-206.

Rauch, J. E. 2001. Business and social networks in international trade, Journal of Economic Literature XXXIX: 1177-1203. http://dx.doi.org/10.1257/jel.39.4.1177

Raynauld, A. 1992. Financing exports to developing countries. Development Centre Studies, Paris: OECD.

Richardson, C. J. 2011. Perception of export barriers in a high-tech sector in a less developed country: the case of ICT SMEs in Malaysia, The South East Asian Journal of Management 2(2): 91-105.

Richardson, J. D. 1993. Sizing up U.S. export disincentives. Washington, DC: Institute for International Economics.

Rundh, B. 2007. International marketing behaviour amongst exporting firms, European Journal of Marketing 41(1/2): 181-198. http://dx.doi.org/10.1108/03090560710718175

Shaw, V.; Darroch, J. 2004. Barriers to internationalisation: a study of entrepreneurial new ventures in New Zealand, Journal of International Entrepreneurship 2(4): 327-343.

http://dx.doi.org/10.1007/s10843-004-0146-6

Silva, J. R. 2008. Internationalization strategies in iberoamerican: the case of Portuguese trade: Project Documents Collection. Santiago de Chile: Economic Commission for Latin America and the Caribbean (ECLAC), United Nations Publications.

Silva, J. R.; Simões, C. C. 2012. Portuguese exports and FDI: observations from the firms' perspective, China-USA Business Review 11(6): 820-835.

Sourdin, P.; Pomfret, R. 2012. Trade facilitation: defining, measuring, explaining and reducing the cost of international trade. Cheltenham, UK: Edward Elgar.

http://dx.doi.org/10.4337/9780857937438

Strandholm, K.; Kumar, K. 2003. Differences in environmental scanning activities between large and small organizations: the advantage of size, Journal of American Academy of Business 3(1/2): 416-421.

Suarez-Ortega, S. 2003. Export barriers: insights from small and medium-sized firms, International Small Business Journal 21(4): 403-419. http://dx.doi.org/10.1177/02662426030214002

Sullivan, D.; Bauerschmidt, A. 1988. Common factors underlying incentive to export: studies in the European forest products industry, European Journal of Marketing 22(10): 41-55.

http://dx.doi.org/10.1108/EUM0000000005303

Tesfom, G.; Lutz, C. 2006. A classification of export marketing problems of small and medium sized manufacturing firms in developing countries, International Journal of Emerging Markets 12(3): 262-281. http://dx.doi.org/10.1108/17468800610674480

Thomas, M.; Araujo, L. 1985. Theories of export behavior a critical analysis, European Journal of Marketing 19(2): 42-52. http://dx.doi.org/10.1108/EUM0000000004751

Uner, M. M.; Kocak, A.; Cavusgil, E.; Cavusgil, S. T. 2013. Do barriers to export vary for born globals and across stages of internationalization? An empirical inquiry in the emerging market of Turkey, International Business Review 22(5): 800-813.

http://dx.doi.org/10.1016/j.ibusrev.2012.12.005

Vivekanandan, K.; Rajendran, R. 2006. Export marketing and the world wide web: perceptions of export barriers among Tiupur Knitwear Apparel Exporters - an empirical analysis, Journal of Electronic Commerce Research 7(1): 27-41. 
Wheeler, C.; Ibeh, K.; Dimitratos, P. 2008. UK export performance research: review and implications, International Small Business Journal 26(2): 207-239.

http://dx.doi.org/10.1177/0266242607086574

Zammit, B.; Ross, D. G.; Wood, D. 2009. Perceptions of export credit insurance value: Australian evidence, Asian-Pacific Journal of Business Administration 1(2): 109-118.

http://dx.doi.org/10.1108/17574320910989078

Joaquim Ramos SILVA is an Associate Professor at the School of Economics and Management, University of Lisbon, and a member of SOCIUS/CSG, a FCT research centre. He has published many scientific papers in journals and collective books; among others, his articles were published in Business Process Management Journal, Journal of Economic Studies, Journal of Enterprise Information Management, Letters in Spatial and Resource Sciences, Studies in Regional Science, Tourism Management.

Mário FRANCO is an Assistant Professor of Entrepreneurship and SME Administration at the Department of Management and Economics, Beira Interior University, Portugal. He received his $\mathrm{PhD}$ in Management from Beira Interior University in 2002. His research focuses on strategic alliances, business networks, innovation and business creation. He is also a member of a Research Center (CEFAGE-UBI) and currently involved in several research projects on SMEs.

André MAGRINHO received his $\mathrm{PhD}$ in Management from Beira Interior University (UBI) in 2009. At present, he carries out functions as Assistant to the President of the AIP Foundation. Areas of investigation: economic, innovation and competitiveness, competitive intelligence and economic diplomacy. 